\title{
Transformation of educational structures: university as an entrepreneurial organization
}

\section{Transformação das estruturas educacionais: universidade como organização empreendedora}

\section{Transformación de las estructuras educativas: la universidad como organización emprendedora}

\author{
Aida Vasiljevna Kormishova ${ }^{1}$ (D), Maria Valeryevna Maltseva ${ }^{1}$ (i), \\ Aleksey Viktorovich Aleshkov² iD, Aleksey Valeryevich Novikov ${ }^{3}$ iD, \\ Diana Nikolaevna Slabkaya ${ }^{4}$ iD

\footnotetext{
${ }^{1}$ State University of Management, Moscow, Russian Federation.

2 Khabarovsk State University of Economics and Law, Khabarovsk, Russian Federation.

${ }^{3}$ Research Institute of the Federal Penitentiary Service of Russia, Moscow, Russian Federation; Astrakhan State University, Astrakhan, Russian Federation.

${ }^{4}$ Research Institute of the Federal Penitentiary Service of Russia, Moscow, Russian Federation.
}

\section{Corresponding author:}

Aida Vasiljevna Kormishova

Email: AidaKormishova@yandex.ru

Kormishova, A. V., Maltseva, M. V., Aleshkov, A. V., Novikov, A. V., \& Slabkaya, D. N. (2021). Transformation of educational structures: university as an entrepreneurial organization. Revista Tempos e Espaços em Educação, 14(33), e16389. http://dx.doi.org/10.20952/revtee.v14i33.16389

\begin{abstract}
The response of the higher education system to the challenges of today is the emergence and development of new forms of university activity, which more adequately correspond to modern realities. One of these forms is entrepreneurial universities. Thus, this study aims to determine the features of the transformation of universities into entrepreneurial organizations. The article reviews the scientific literature on the problem under study and presents options for defining an entrepreneurial university. Based on an expert survey, the areas of university entrepreneurial activity are determined. The authors indicate the features of entrepreneurial universities and establish and analyze methods for transforming universities in the direction of entrepreneurship. The study led to the conclusion that transformational change in universities is a prerequisite for their effective transformation into entrepreneurial universities.
\end{abstract}

Keywords: Entrepreneurial university. Entrepreneurship. Entrepreneurial activity. Educational model. 


\section{RESUMO}

A resposta do sistema de ensino superior aos desafios da atualidade é o surgimento e o desenvolvimento de novas formas de atividade universitária, que correspondam mais adequadamente às realidades modernas. Uma dessas formas são as universidades empreendedoras. Assim, este estudo tem como objetivo determinar as características da transformação das universidades em organizações empreendedoras. O artigo faz uma revisão da produção científica sobre o problema em estudo e apresenta opções para definir uma universidade empreendedora. Com base na pesquisa de especialistas, são determinadas as áreas de atividade empreendedora universitária. Os autores indicam as características das universidades empreendedoras e estabelecem e analisam métodos para transformar as universidades na direção do empreendedorismo. O estudo levou à conclusão de que a mudança transformacional nas universidades é um pré-requisito para sua transformação efetiva em universidades empreendedoras.

Palavras-chave: Universidade empreendedora. Empreendedorismo. Atividade empreendedora. Modelo educacional.

\section{RESUMEN}

La respuesta del sistema de educación superior a los desafíos de hoy es el surgimiento y desarrollo de nuevas formas de actividad universitaria, que se correspondan más adecuadamente con las realidades modernas. Una de estas formas son las universidades emprendedoras. Así, este estudio tiene como objetivo determinar las características de la transformación de las universidades en organizaciones emprendedoras. El artículo revisa la literatura científica sobre el problema en estudio y presenta opciones para definir una universidad emprendedora. A partir de una encuesta a expertos, se determinan las áreas de actividad emprendedora universitaria. Los autores señalan las características de las universidades emprendedoras y establecen y analizan métodos para transformar las universidades en la dirección del emprendimiento. El estudio llevó a la conclusión de que el cambio transformacional en las universidades es un requisito previo para su transformación efectiva en universidades emprendedoras.

Palabras clave: Universidad emprendedora. Emprendimiento. Actividad emprendedora. Modelo educativo.

\section{INTRODUCTION}

The interaction between educational and business environments is an interesting problem from the point of view of the current state of civilization, characterized by radical changes in its fundamental institutions (Terenteva et al., 2017; Plenkina \& Deberdieva, 2017). A striking manifestation of such interaction is the model of an entrepreneurial university, the essence of which is in the implementation of the principles of the business environment in the academic sphere (Beknazarov et al., 2020; Zabolotnikova et al., 2020; Goncharov et al., 2020; Abdulkadirov et al., 2020).

Entrepreneurial universities challenge the traditional, retro-oriented university model with the defining principles of the business environment functioning. Generally speaking, entrepreneurial universities purposefully try to function in the business environment (Biryukov et al., 2020; Dudin et al., 2019, 2020).

According to global statistics, budgetary financial support of state universities by many countries now covers only about $30 \%$ of their total expenses (Kalenyuk \& Dyachenko, 2016). In such conditions, universities of various types must find the rest of the funds and their sources on their own (Obedkova et al., 2020). This fundamentally changes the principles and foundations of national higher education policy supporting universities funded from the state or local budget. Universities 
of all types are forced to focus on finding alternative sources of funding and its diversification and attracting additional financial sources (Dudin et al., 2018).

Therefore, "one of the methods to quickly respond to the demands of the economy and industry can be the use of the model of 'innovative' or 'entrepreneurial university' by several universities and technical colleges with a program close to university programs. Strengthening the position of entrepreneurial universities with a decrease in public funding and significant dependence on the state makes universities look for other methods to stabilize their financial situation" (Sam \& van der Sijde, 2014, p. 899).

Entrepreneurial universities, which focus on effective management aimed at successful positioning as central institutions of the knowledge economy and influential players in both national and global labor markets, are today a popular topic of discussion among education experts (Philpott et al., 2011).

\section{Literature review}

Henry Etzkowitz and Burton Clark are considered the authors of the concept of an entrepreneurial university (Bronstein \& Reihlen, 2014). H. Etzkowitz first presented the concept of an entrepreneurial university in 1983. According to Etzkowitz (1983), universities consider the possibility to find new sources of funding by obtaining patents for discoveries made as a result of agreements concluded by universities for the sale of knowledge and research carried out under contracts with commercial firms and private business partners.

Let us consider the most frequently used definitions of the concept of an entrepreneurial university, introduced by scholars and specialists in university entrepreneurship (Table 1).

Table 1. Definitions of the concept of an entrepreneurial university.

\begin{tabular}{|c|c|}
\hline Source & Definition of an entrepreneurial university \\
\hline Schulte P. (2004) & $\begin{array}{l}\text { "Entrepreneurial university" can have three meanings: a university becomes entrepreneurial } \\
\text { as an organization; university faculty members, students, and employees become } \\
\text { entrepreneurs; the interaction between the university and the exterior, which is, in other } \\
\text { words, a "structural link" between the university and the region, becomes entrepreneurial }\end{array}$ \\
\hline Finlay I. (2004) & $\begin{array}{l}\text { Entrepreneurial universities are characterized by closer cooperation between universities and } \\
\text { businesses, greater responsibility of employees for the availability of external sources of } \\
\text { funding, as well as a managerial ideal of institutional management, administration, and } \\
\text { planning }\end{array}$ \\
\hline $\begin{array}{l}\text { Guenther J., } \\
\text { Wagner K. (2008) }\end{array}$ & $\begin{array}{l}\text { Entrepreneurial universities can innovate, identify, and create opportunities, work in teams, } \\
\text { take risks, and respond to the challenges }\end{array}$ \\
\hline $\begin{array}{l}\text { Etzkowitz H. } \\
(2004)\end{array}$ & $\begin{array}{l}\text { Just as a university prepares students and sends them out into the world, an entrepreneurial } \\
\text { university is a natural incubator that structurally supports and helps faculty members and } \\
\text { students to set up new intellectual, commercial, and collaborative companies }\end{array}$ \\
\hline Cargill B. (2007) & $\begin{array}{l}\text { Entrepreneurial universities are based on both commercialization (traditionally or historically } \\
\text { established continuous education courses, consulting services, and expansion) and } \\
\text { commoditization (distribution of patents, licensing, or student start-ups) }\end{array}$ \\
\hline Gibb A.A. \& & The main principles of an entrepreneurial university are: 1) the ability of academic \\
\hline $\begin{array}{l}\text { Hannon P.D. } \\
(2006)\end{array}$ & $\begin{array}{l}\text { administration to define strategic goals and achieve them; } 2 \text { ) legal control over academic } \\
\text { resources, including tangible property, such as university buildings, and intellectual property } \\
\text { in the form of research results; } 3 \text { ) organizational ability to transfer technology through } \\
\text { patenting, licensing, and creating incubators; } 4 \text { ) corporate entrepreneurial ethics among } \\
\text { representatives of the administration, faculties, and students }\end{array}$ \\
\hline $\begin{array}{l}\text { Guerrero M. \& } \\
\text { Urbano D. (2012) }\end{array}$ & $\begin{array}{l}\text { An entrepreneurial university is a modern phenomenon, which is the implementation by the } \\
\text { scientific community of a new mode of production based on the continuous appearance of } \\
\text { organizational and technological innovations }\end{array}$ \\
\hline
\end{tabular}

Research hypothesis: transformational change in universities is a prerequisite for the effective transformation of these universities into entrepreneurial universities. 
Research objectives:

1. to identify the areas of university entrepreneurial activity;

2. to indicate the features of an entrepreneurial university;

3. to identify and analyze methods of transformation of universities into entrepreneurial universities.

The article consists of an introduction, literature review, description of research methods, research results and their discussion, and conclusion.

\section{METHODS}

To achieve the study goal, we applied the following research methods: theoretical methods (analysis, synthesis, comparison, generalization) for the review of the scientific literature on the state of the research problem; empirical methods (expert survey); numerical methods (method of mathematical processing of respondents' answers).

The main research method was an online expert survey, during which experts were asked to answer the questions posed to obtain information about the areas of entrepreneurial activity of a university, the features of an entrepreneurial university, and methods of transformation of universities into entrepreneurial universities.

The experts were 20 workers from the administrations of two Russian universities. According to the selection criterion, the experts had been working for at least 8 years in management in educational management.

All participants were informed about the purpose of the survey and knew that the authors of the survey would publish the summary of the results.

The study of the transformation of universities into entrepreneurial universities was carried out in three stages:

the preparatory stage, during which the aim of the study and research hypothesis were formulated and the questions for the experts were developed;

the main stage, which was carried out within 15 days and included the online expert survey;

the final stage, during which the analysis, interpretation, and processing of the results were carried out.

\section{RESULTS}

The experts noted that the following may become the areas of university entrepreneurial activity (Table 2 ).

Table 2. Areas of university entrepreneurial activity.

\begin{tabular}{|c|c|c|}
\hline No. & Areas of entrepreneurial activity & \%* \\
\hline 1 & $\begin{array}{l}\text { various educational services and funded scientific research on a contractual basis with the } \\
\text { subsequent designing of equipment, technologies, methods, techniques, know-how, etc. }\end{array}$ & $90 \%$ \\
\hline 2 & preparation of teaching materials on a contractual basis (textbooks, manuals, etc.) & $87.5 \%$ \\
\hline 3 & $\begin{array}{l}\text { scientific and professional examinations, education of highly qualified specialists on a } \\
\text { contractual basis (master's degree, doctorate) }\end{array}$ & $85 \%$ \\
\hline 4 & $\begin{array}{l}\text { organization of various international educational, scientific, cultural, athletic, and } \\
\text { entertainment programs (both at home for foreigners in their country and abroad for citizens } \\
\text { of their country) }\end{array}$ & $85 \%$ \\
\hline 5 & $\begin{array}{l}\text { organization of children and schoolchildren courses according to the programs of preschool } \\
\text { and school education institutions }\end{array}$ & $82.5 \%$ \\
\hline 6 & $\begin{array}{l}\text { organization of various educational, cultural, athletic, recreational, and other events by the } \\
\text { staff of universities and leasing university resources to third-party legal entities for similar } \\
\text { purposes }\end{array}$ & $80 \%$ \\
\hline 7 & $\begin{array}{l}\text { provision of the following services to applicants and students: vocational guidance; search for } \\
\text { internship and employment assistance; consultations for foreign students on migration issues }\end{array}$ & $75 \%$ \\
\hline
\end{tabular}


and search for accommodation and temporary employment; help for applicants and students in finding sources of financial support for their studies assistance services; Internet clubs, etc.)

Note: compiled based on the expert survey; ${ }^{*}$ - percentage of expert references

Based on the expert survey, the following main features of an entrepreneurial university were identified (Table 3).

Table 3. Features of an entrepreneurial university.

\begin{tabular}{|c|c|c|c|}
\hline No. & Feature & Characteristics & \%* \\
\hline 1 & $\begin{array}{ll}\text { Independence } & \text { from } \\
\text { government funding } & \end{array}$ & $\begin{array}{l}\text { The university does not need to obtain permission or approval } \\
\text { from the government to receive investments. For example, to } \\
\text { create new scientific directions, form new branches or } \\
\text { commercial structures, etc. }\end{array}$ & $90 \%$ \\
\hline
\end{tabular}

2 Focus on the central core of There is a strong, decision-making top group that manages the governance business. The involvement of a wider academic and student community in this process is less important

$3 \quad$ Employees' qualifications in The university employs highly qualified professionals and offers a management, especially in sufficient number of relevant professional development finance programs to increase their contribution to entrepreneurial development

4 Opportunities for selfThe university is given broad powers to use government funds formation (change) of the freely. For example, the university can reallocate funds between budget workers, IT, and other infrastructures and investments and can also retain annual unspent money (for example, to create strategic funds)

$5 \quad$ Externally focused financial contracts

Government and non-government funds and other sources of funding are calculated according to the necessary expenses and business results. This is monitored through regular reports

6 Collaboration with industry The university implements synergy opportunities in research, and other leading investment in research equipment, teaching, and other useful universities activities with a network of different individuals and institutions

7 Additional funding from the so-called "cash cows" Creation of a third stream of income in addition to budgetary financing and industrial investment, for example: conferences halls, management and business schools, other opportunities for lifelong education, shops with university products, educational and scientific literature, etc.

$8 \quad$ Optimal focus on a limited University management should not be wasted on too diversified range of disciplines and research activities in areas not related to the main area of university activity (know-how)

$9 \quad$ Monitoring future teaching and research opportunities

The university sees a current situation of the development of the educational, educational services, and scientific research markets; it systematically studies them and accumulates resources to quickly respond to any options for the development or changes of such markets

10 Attractiveness donations

for The university image, its projects, the level of preparation, and the quality of graduates' qualification attract regular and substantial donations (sponsorship fees)

11 Attractive conditions for The university hires successful young scientists and accepts and young scientists

12 Technology transfer creates necessary conditions. This contributes to both attracting more students and carrying out innovative research There are well-functioning and structured technology transfer processes 
According to the experts, universities can transform successfully only with the help of entrepreneurial actions. Five main elements make up the minimum in this process (Table 4).

Table 4. The methods of transformation of universities into entrepreneurial universities.

\begin{tabular}{lll}
\hline No. & Methods of transformation & $\% *$ \\
\hline 1 & Reinforced directing center (management core) & $90 \%$ \\
2 & Expanded periphery as a development environment & $87.5 \%$ \\
3 & Funding diversification & $85 \%$ \\
4 & Constantly stimulated academic environment & $85 \%$ \\
5 & Integrated entrepreneurship & $82.5 \%$ \\
\hline
\end{tabular}

Note: compiled based on the expert survey; ${ }^{*}$ - percentage of expert references

\section{DISCUSSION}

Let us consider in more detail the methods of transformation of universities into entrepreneurial universities.

Reinforced directing center (management core). According to the experts, this center can take various forms, but "it should cover central management groups and academic units, such as departments, etc. The center should combine new management values with traditional academic values" (Expert 12).

Expanded periphery as a development environment. Entrepreneurial universities' units, which overcome old university boundaries and connect with organizations and groups in the outside world, growing rapidly. "On the one hand, such units are professional units whose activities are aimed at transferring knowledge, contacting with the industry, developing intellectual property, offering lifelong education, and fundraising and maintaining relations with the graduates. On the other hand, such units (departments) are interdisciplinary research centers focused on solving scientific problems and carrying out projects" (Expert 9). "Academic units, based on only one domain, will continue to play an important role in the future. Yet, such units cannot carry out all activities (a set of entrepreneurial actions) that universities now need to carry out" (Expert 17). Research centers focused on the external environment have a certain flexibility and are easy to establish and restructure. Such centers are the mediators between the university units and the outside world.

The university infrastructure should rapidly develop, improve, and keep up with the development of the university interaction (trading in results of educational, scientific, and technical activities) with external groups (Rothaermel et al, 2007). Therefore, the evolution of a traditional university into entrepreneurial takes place in this way.

Funding diversification. The experts believed that universities need greater financial resources to design their new, change-oriented nature. Analyzing possible methods to diversify the already existing funds of entrepreneurial universities, G.D. Meyer (2011) identifies three sources of income: 1 ) the main is the financial support from the government (Ministry of Education); 2) state research funds are also important; 3 ) all other resources are defined as the third source of income. This diversification is essential for entrepreneurial universities. This makes it possible to move forward, making up for the losses, and follow the rule "It is better to have more money than less, but it should be obtained in a legal way" (Expert 19).

Speaking of the third source, the experts believed that it can include:

- other income from the government: the regional or city (municipal) authorities or other ministries (Ministries of Agriculture, Forestry, Ecology, Emergency Situations, Science and Technology, Economic Development, etc.);

- private sources (private organizations), including:

a) industrial companies with a large number of sectors and important differences between small and large companies; 
b) professional and local (regional, city, municipal) associations and organizations that are interested in providing education to their employees;

c) philanthropic funds, which can be both small and large;

- income received by the university from its statutory activities; from deposits and investments; from campus (from health centers or university hospitals to bookstores); from students (fees for tuition and services); from university graduates' funds; from the patented intellectual property of universities and teachers (royalty payments).

D. Audretsch (2014) notes that the third source of income has no limits. This support provided by regional and city authorities, as well as university graduates, grows every year in many universities around the world.

In the process of seeking additional funding from the second and third sources, entrepreneurial universities, in comparison with non-entrepreneurial, are better aware that funding diversification makes them more mobile and independent of government regulation, standard rules, instructions, etc. (Brennan et al., 2005).

According to researchers, discretionary funds (money that is available to spend on things that are not considered necessary by the educational institution) are of particular importance (Rothaermel et al., 2007).

Constantly stimulated academic environment. Creating a strong directing center, expanding the periphery, and diversifying the income, an entrepreneurial university's core still belongs to the traditional academic departments, either focusing on several disciplines or interdisciplinary nature. The proposed changes and innovative steps, according to the experts, can fail in these units of the academic core of the university. "If the main academic departments are opposed to innovation and do not accept it, the life of the university will continue as it used to. To change, units and teachers must one by one become business units and entrepreneurs by creating new programs and measures to make a profit" (Expert 15). The correct perception of management measures and the creation of the honor system in a university's entrepreneurship is especially important in the academic environment (Markuerkiaga et al., 2014).

Integrated entrepreneurship. Entrepreneurial universities, just like any company, develop a corporate culture that welcomes, perceives, and supports changes. This new culture can start with even a small institutional idea of change. In the future, this idea can and must develop to create a new innovative university culture on its basis. "The issue of university culture is becoming important because institutional culture helps to cultivate institutional affiliation and a certain reputation" (Expert 9). "In the transformation of universities, the values and ethical beliefs of the educational institution can lead to the development of other important elements" (Expert 6).

Analyzing the appearance and development of entrepreneurial culture in European universities, M. Shattock (2005) notes that the European universities' activities differ from traditional academic activities, such as teaching, research, and cultural services to society. Such issues as the economic component of a university's activities, funding, and methods of making a profit have come to the fore. These issues, faced by almost all universities and colleges in Europe, are fundamentally different from those of classical universities of the past. A significant place in the activities of any university is now occupied by such components of entrepreneurship as consulting, franchising, marketing and management, and student loans. Besides, preference is given to funded research (and research that can be profitably sold); wide internationalization of education and the invitation to study for foreign students; the commercialization of all types of activities of universities, including the use of campuses on a commercial basis, leasing university premises, gyms, and grounds to non-students and non-residents, etc. The scale and volume of commercial services currently provided by universities and colleges depend on their characteristics and location, and the efficiency of university business activities depends on market orientation and technologies. 


\section{CONCLUSION}

The formation of the effective interaction between academic and entrepreneurial institutions has become a prerequisite for radical changes in the system of university education and the formation of the global educational space. At the ideological level, entrepreneurial institutions enter the sphere, traditionally belonging to educational institutions in general and structures of university education in particular. Such interaction is considered in Western literature the "second academic revolution" ( $\mathrm{H}$. Etzkowitz), which logically continues the first: the combination of education and research.

As a result of such interaction, we examined the model of an entrepreneurial university, the essence of which is in the implementation of the principles of the business environment in the academic sphere.

The main features of an entrepreneurial university, as well as entrepreneurial activity in the field of higher education in general, are the need for the mandatory preservation of the academic and scientific character and a high level of educational services and scientific research; support of high moral and ethical standards of the university environment; preservation of educational and scientific cultural traditions and previous achievements; high image and augmentation of the merits of the university and the entire system of higher education.

The research has confirmed the hypothesis that transformational change in universities is a prerequisite for the effective transformation of these universities into entrepreneurial universities.

Authors' Contributions: Kormishova, A. V: conception and design, acquisition of data, analysis and interpretation of data, drafting the article, critical review of important intellectual content. Maltseva, M. V: conception and design, acquisition of data, analysis and interpretation of data, drafting the article, critical review of important intellectual content. Aleshkov, A. V: conception and design, acquisition of data, analysis and interpretation of data, drafting the article, critical review of important intellectual content. Novikov, A. V: conception and design, acquisition of data, analysis and interpretation of data, drafting the article, critical review of important intellectual content. Slabkaya, D. N: conception and design, acquisition of data, analysis and interpretation of data, drafting the article, critical review of important intellectual content. All authors have read and approved the final version of the manuscript.

Ethics Approval: Not applicable.

Acknowledgments: Not applicable.

\section{REFERENCES}

Abdulkadirov, U. U., Lukovtseva, A. K., \& Osmanov, R. T. (2020). Development of small business in rural settlements. Revista Inclusiones, 7(Especial), 376-386.

Audretsch, D. (2014). From the entrepreneurial university to the university for the entrepreneurial society. Journal of Technological Transfer, 39, 313-321. http://dx.doi.org/10.1007/s10961-012-9288-1

Beknazarov, B., Niyazbekova, R., Amirseitov, U., Kokenova, A., Daurbayeva, M., \& Aitkazina, M. (2020). Development of entrepreneurship and forms of self-employment in the innovative sectors of the economy. Entrepreneurship and Sustainability Issues, 8(2), 209-228. https://doi.org/10.9770/jesi.2020.8.2(13)

Biryukov, V. A., Dmitieva, O. V., Frolova, V. B., Nikandrova, L. K., \& Arkhipov, A. B. (2020). Formation of a Tourism Entrepreneurial Environment in the Conditions of Competition. Journal of Environmental Management and Tourism, 10(8), 1779-1784. https://doi.org/10.14505/jemt.v10.8(40).08

Brennan, M. C., Wall, A. P., \& McGowan, P. (2005). Academic entrepreneurship: Assessing preferences in nascent entrepreneurs. Journal of Small Business \& Enterprise Development, 12(3), 307-322.

Bronstein, J., \& Reihlen, M. (2014). Entrepreneurial university archetypes: A meta-synthesis of case study literature. Industry \& Higher Education, 28(4), 245-262.

Cargill, B. (2007). Learning about the entrepreneurial university: Do we know what it means? Do we know what it takes to succeed. South African Journal of Higher Education, 21(3), 373-383. 
Dudin, M. N., Ivashchenko, N. P., Gurinovich, A. G., Tolmachev, O. M., \& Sonina, L.A. (2019). Environmental entrepreneurship: characteristics of organization and development. Entrepreneurship and Sustainability Issues, 6(4), 1861-1871. https://doi.org/10.9770/jesi.2019.6.4(22)

Dudin, M. N., Nikandrova, O. A., Ivashchenko, N. P., Bulygina, N. I., Vysotskaya, N. V., \& Pak, O. A. (2018). Fostering Social Entrepreneurship as an Effective Tool for Resolving Social Issues in Society: International and Russian Practices (the Case of Moscow Oblast). Option, 34(85), 944-955.

Dudin, M. N., Shakhov, O. F., Ivashchenko, N. P., \& Shakhova, M. S. (2020) Development of entrepreneurial competencies in the economy (evidence from digital entrepreneurship). Revista Inclusiones, 7(Especial), 54-68.

Etzkowitz, H. (1983). Entrepreneurial scientists and entrepreneurial universities in American academic science. Minerva, 21(2-3), 198-233. https://doi.org/10.1007/bf01097964

Etzkowitz, H. (2004). The evolution of the entrepreneurial university. International Journal of Technology and Globalization, 1(1), 64-77. http://dx.doi.org/10.1504/IJTG.2004.004551

Finlay, I. (2004). Living in an entrepreneurial university. Research in Post-Compulsory Education, 9(3), 421-434. http://dx.doi.org/10.1080/13596740400200187

Gibb, A. A., \& Hannon, P. D. (2006). Towards the Entrepreneurial University. International Journal of Entrepreneurship Education, 4, 73-110.

Goncharov, V. V., Sekerin, V. D., \& Akhyadov, E. S.-M. (2020). Digital academic entrepreneurship: new opportunities for students in the development of the information environment. Revista Inclusiones, 7(Especial), 411-421.

Guenther, J., \& Wagner, K. (2008). Getting out of the ivory tower-new perspectives on the entrepreneurial university. European Journal of International Management, 2(4), 400-417. http://dx.doi.org/10.1504/EJIM.2008.021245

Guerrero, M., \& Urbano, D. (2012). The development of an entrepreneurial university. The Journal of Technological Transfer, 37(1), 43-74. http://dx.doi.org/10.1007/s10961-010-9171-x

Kalenyuk, I., \& Dyachenko, A. (2016). Entrepreneurial universities in a world educational system. International Economic Policy, 25(2), 59-74.

Markuerkiaga, L., Errasti, N., \& Igartua, J. I. (2014). Success factors for managing an entrepreneurial university: Developing an integrative framework. Industry and Higher Education, 28(4), 233-244.

http://dx.doi.org/10.5367/ihe.2014.0214

Meyer, G. D. (2011). The reinvention of academic entrepreneurship. Journal of Small Business Management, 49(1), 18. http://dx.doi.org/10.1111/j.1540-627X.2010.00311.x

Obedkova, L. P., Efremov, A. A., Sekerin, V. D., Gorokhova, A. E., \& Slepov. V. A. (2020). Formation of Competencies in Higher Education by Bachelors and Masters. Utopía y Praxis Latinoamericana, 25(Extra 5), 215-220.

Philpott, K., Dooley, L., O’Reilly, C., \& Lupton, G. (2011). The entrepreneurial university: Examining the underlying academic tensions. Technovation, 31, 161-170. http://dx.doi.org/10.1016/j.technovation.2010.12.003

Plenkina, V. V., \& Deberdieva, N. P. (2017). The peculiarities of the establishment of partner relations between local self-government bodies and entrepreneurs. Academy of Strategic Management Journal, 16(Sp 2), 1-8.

Rothaermel, F. T., Agung, S. D., \& Jiang, L. (2007). University entrepreneurship: A taxonomy of the literature. Industrial and Corporate Change, 16(4), 691-791. http://dx.doi.org/10.1093/icc/dtm023

Sam, C., \& van der Sijde, P. (2014). Understanding the concept of the entrepreneurial university from the perspective of higher education models. Higher Education, 68(6), 891-908. http://dx.doi.org/10.1007/s10734-014-9750-0

Schulte, P. (2004). The entrepreneurial university: A strategy for institutional development. Higher Education in Europe, 29(2), 187-191. http://dx.doi.org/10.1080/0379772042000234811

Shattock, M. (2005). European universities for entrepreneurship: Their role in the Europe of knowledge: The theoretical context. Higher Education Management and Policy, 17(3), 13-25.

Terenteva, T. V., Shashlo, N. V., \& Kuzubov, A. A. (2017). Conceptual approach to the process of strategic positioning of business entities of the fishing industry. Academy of Strategic Management Journal, 16(Sp 2), 1-13.

Zabolotnikova, V., Selezneva, I., Nizamdinova, A., Mukhamedyarova-Levina, T., \& Praliyeva, S. (2020). Entrepreneurial projects' development: alternative sources of investments. Entrepreneurship and Sustainability Issues, 8(2), 253-268. https://doi.org/10.9770/jesi.2020.8.2(15) 
Received: 31 May 2021 | Accepted: 22 August 2021 | Published: 5 September 2021

(c) (1)

This is an Open Access article distributed under the terms of the Creative Commons Attribution License, which permits unrestricted use, distribution, and reproduction in any medium, provided the original work is properly cited. 